James Carleton Paget

\title{
Jews, Christians and Jewish Christians in Antiquity
}

[Juden, Christen und jüdische Christen in der Antike.]

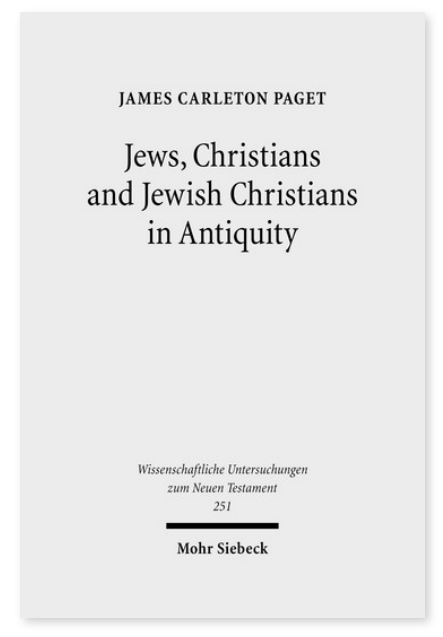

2010. XV, 538 Seiten. WUNT I 251

ISBN 978-3-16-151540-8

DOI 10.1628/978-3-16-151540-8

eBook PDF 159,00€

ISBN 978-3-16-150312-2

Leinen $159,00 €$
Veröffentlicht auf Englisch.

James Carleton Paget untersucht eine Vielzahl von Themen, die für die Untersuchung des antiken Judentums und Christentums und ihre Interaktion bedeutend sind. Dabei berücksichtigt er die Polemik, die Bekehrung, die biblische Interpretation, den Messianismus, das Phänomen, das normalerweise als jüdisches Christentum beschrieben wird und das Schicksal der jüdischen Gemeinde nach der Bar-Kochba Revolte in einer Zeit, die für die Entstehung sowohl des Judentums als auch des Christentums von großer Bedeutung war. Der Autor verfolgt keine bestimmte These, sondern versucht, die bedeutendsten Spannungslinien in der gegenwärtigen Debatte über diese fraglichen Themen aufzuzeigen und dabei ihren komplexen und verworrenen Charakter zu enthüllen.

James Carleton Paget Born 1966; 1992 PhD at Cambridge University; currently Senior Lecturer in New Testament Studies at the University of Cambridge and a Fellow and Tutor of Peterhouse.
Jetzt bestellen:

https://mohrsiebeck.com/buch/jews-christians-and-jewish-christians-in-antiquity-9783161515408?no_cache=1

order@mohrsiebeck.com

Telefon: +49 (0)7071-923-17

Telefax: +49 (0)7071-51104 